\title{
THE PROBLEM OF HEAT RESISTANCE OF MICRO-ORGANISMS IN THE BRITISH SPONTANEOUS GENERATION CONTROVERSIES OF $1860-1880$
}

by

\section{J. K. CRELLIN*}

BEFORE there could be complete acceptance of the theory that fermentations, putrefactions and infectious diseases were caused by existing micro-organisms (the germ theory) it was necessary to disprove the theory of the spontaneous generation of such organisms. As is well known, this was largely accomplished by Pasteur, around 1860 , in spite of the spirited opposition of Pouchet. Later, Tyndall's studies on resistant germs ${ }^{1}$ (1877) did much to explain the remaining difficulties in sterilising certain infusions. It is perhaps less well known that in the years between the studies by Pasteur and Tyndall there were many controversies in Britain over spontaneous generation. These were particularly prominent from 1870 when that argumentative and staunch supporter of spontaneous generation, $\mathrm{H}$. Charlton Bastian, entered the scene. During the next eight years or so Bastian was often in violent controversy with such opponents of spontaneous generation as T. H. Huxley, E. Ray Lankester, W. Roberts, J. Burdon Sanderson and J. Tyndall.

These controversies were of wide general interest and not restricted to the scientific and medical press, for articles also appeared in The Contemporary Review and The Nineteenth Century, and there were repeated discussions at the British Association meetings. Undoubtedly such general interest was fostered by the relevance of spontaneous generation to the big topic of debate at the time, evolution and its theological implications. ${ }^{2}$

One of the main points of this widespread controversy was the question of the survival of micro-organisms in heated solutions. Following Pasteur's work it was generally held that solutions could be sterilised by boiling for a few minutes or, in some cases, by heating to $110^{\circ} \mathrm{C}$. However, there remained the problem of explaining the occasional appearance of micro-organisms in solutions which were supposedly sterile and which apparently had not been contaminated after the sterilisation process. This was thought to be strong evidence for spontaneous generation by supporters

* Maccabaean Prize Essay, Faculty of the History of Medicine and Pharmacy, 1965.

\footnotetext{
${ }_{1}$ During the period under review the word germ referred to what was thought to be a precursor of an adult micro-organism. Germs were considered to be either airborne particles which could be collected and microscopically examined, or ultra-microscopic particles only visible by their scattering effect on a beam of light. Though such ideas of germs were later shown to be erroneous, Tyndall's studies, which were concerned with ultra-microscopic germs, were still valuable for they had shown that some micro-organisms have a resistant phase in their life cycle. This is now known to be due to spore formation.

- More complete background information to this essay can be found in a dissertation entitled 'Spontaneous Generation and the Germ Theory (1860-1880): the Controversy in Britain and the Work of F. Crace Calvert', submitted by the writer for the University of London M.Sc. degree in the History and Philosophy of Science.
} 
of the doctrine. On the other hand, its opponents commonly held that such growth was due to the introduction of airborne micro-organisms through bad experimental technique. Although there was a considerable element of truth in this argument it was not sufficiently discriminating when the work of Child, Bennett and Bastian, the three main British supporters of spontaneous generation, is considered. They appear to have taken great care to avoid contamination of the solutions they thought to be sterile. Not surprisingly, therefore, there was early consideration of an alternative explanation of growth in infusions after sterilisation, namely that micro-organisms had survived the sterilisation process. Thus it was that during the years $1860-1880$ it was slowly realised that certain organisms have a heat resistant stage in their life cycles. After 1880 it only remained to build up a body of evidence to establish fully the conditions and extent of such resistance.

It is the purpose of this essay to look at the rise, during the years $1860-1880$, of the fundamental concept of heat resistance of micro-organisms. In so doing it will be seen that Tyndall's important work was not isolated and was very much in keeping with many other studies that had been carried out. Special reference will be given to British studies and, as so much valuable work was carried out in Britain, it will be necessary to mention only one or two foreign contributions in order to obtain a clear picture of the establishment of the concept of heat resistance.

Though, as will be seen, all the studies were aimed at throwing light on the spontaneous generation versus germ theory controversies, it should be remembered that they had some direct practical application. For example, Calvert, at the end of one of his papers, indicated that the use of 'public stoves as a means of destroying germ life and contagion' was valueless, as an adequate killing temperature would also damage clothes and bedding etc. ${ }^{3}$ Additionally it is worth noting that the conditions for sterilising injections were generally established before 1880 although the widespread application of this did not come until much later, for sterile injections were not included in the British Pharmacopoeia until 1932.

Up to the time of the first British experimental work on the heat survival of microorganisms, in the early 1870 s, the possibility that micro-organisms might be more resistant than was generally thought was occasionally discussed. This must certainly have helped to give credence to the early experimental work that suggested the idea of resistance. The first such discussion was by Gilbert Child in $1865 . .^{4}$ Child supported spontaneous generation on experimental and theoretical grounds and was considered a 'well-known advocate' of the doctrine. ${ }^{5}$ However, it is important to stress that he

3 'On the action of heat on protoplasmic life dried on in cotton fabrics', Chem. News, 1871, 24, 138-140. Calvert considered that microscopic life was not completely destroyed below $400^{\circ} \mathrm{F}$., a temperature which affected cotton fabrics. His views were not accepted and the Nottingham physician W. H. Ransom was successfully promoting his disinfecting stove for sterilising clothing by heating to between $250^{\circ}$ and $300^{\circ} \mathrm{F}$.

'See his paper, 'Further experiments on the production of organisms in closed vessels', Proc. roy. Soc., 1865, 14, 178-186.

s Nature, Lond., 1870, 2, 417. Child published on the subject on a number of occasions. He discussed his theoretical ideas in Essays on Physiological Subjects, London, 1868, pp. 135-142 and in greater detail in the 2 nd edition of 1869 , pp. 138-155. His experimental work appeared in the paper noted in reference 4 and in an earlier paper 'Experimental researches on spontaneous generation,' Proc. roy. Soc., 1863-64, 13, 313-314. He restated some of his results in 1870 (Nature, Lond.. 1869-70, 1, 626-627, and Report of the British Association for the Advancement of Science 1870, London, 1871, p. 131 of Transactions). 


\section{J.K. Crellin}

always emphasised that his experiments had not proved spontaneous generation. His most important experiments consisted of passing heated air into boiling infusions and, on later examination, finding that growth of micro-organisms had occurred. He concluded that he could not decide between two alternative explanations to account for the growth, either that the resulting micro-organisms had been spontaneously generated or that the 'germs of bacteria' were capable of resisting the heating. He pertinently commented that

upon [the two explanations] I will not return a positive opinion, but remark only, that if it be true that "germs" can resist the boiling temperature in fluid, then both parties in the controversy are working on a false principle, and neither M. Pouchet nor M. Pasteur is likely at present to solve the question of spontaneous generation."

Child raised the same point a little later when commenting on the experiments of the American Jeffries Wyman. ${ }^{7}$ Among many experiments Wyman had shown that growth of micro-organisms could occur in extracts of beef that had been boiled for four hours. Child thought this perhaps indicated that germs were only destroyed when heated to a high temperature for a sufficient time.

It was, however, Huxley, in his presidential address to the British Association meeting of September 1870, who gave the concept of heat resistance particular prominence. To understand the enormous interest taken in Huxley's address, 'Biogenesis and Abiogenesis', 8 it should be mentioned that since January of that year the question of spontaneous generation had been repeatedly raised. For example, Tyndall strongly opposed the idea in his widely reported lecture 'On Dust and Disease'9 and Bastian supported the doctrine in a long article in Nature. ${ }^{10}$ Tyndall and Bastian further expressed their views in an outspoken exchange of letters to The Times. ${ }^{11}$ Huxley's considerable scientific reputation also helped to create interest in his address. It would seem too that his particular statement when accepting the possibility of resistant germs was calculated to arouse the hostility of even the most half-hearted supporter of spontaneous generation for, as he had no experimental evidence, his comment appeared biased. He wrote that if

in the present state of science, the alternative is offered us, either germs can stand a greater heat than has been supposed, or the molecules of dead matter, for no valid or intelligible reason that is assigned, are able to rearrange themselves into living bodies, exactly such as can be demonstrated to be frequently produced in another way, I cannot understand how choice can be, even for a moment, doubtful. ${ }^{12}$

Another staunch opponent of spontaneous generation who, during 1870, mentioned resistance of micro-organisms was Lionel Beale. While commenting on some of

\footnotetext{
- Proc. roy. Soc., 1865, 14, 185.

7 Child's comments appeared in his Essays on Physiological Subjects, London, 1868, p.137. Wyman's experiments caused considerable interest and have been recently described by Doetsch, $R$. $N$., 'Early American experiments on spontaneous generation by Jeffries Wyman (1814-1874)', J. Hist. Med., 1962, 17, 325-332.

${ }^{8}$ Report of the British Association for the Advancement of Science 1870, London, 1871, pp. 1xxiiiIxxxix. Huxley coined the word abiogenesis in place of spontaneous generation.

Proc. roy. Inst. G. B., 1870-72, 6, 1-14.

10 'Facts and reasonings concerning the heterogenous evolution of living things', Nature, Lond., $1870,2,170-177,193-201,219-228$.

11 The Times, 7 April, 1870, p. 5; 13 April, p. 4; 21 April, p. 8; 22 April, p. 5.

12 Report of the British Association for the Advancement of Science 1870, London, 1871, p. 1xxxiii.
} 
Bastian's experiments showing growth in solutions after heating to a temperature of around $150^{\circ} \mathrm{C}$, Beale surprisingly concluded (for like Huxley he had no supporting evidence) that Bastian's results were more in accordance with the idea 'that living forms might live though exposed under certain conditions to a temperature even of $350^{\circ}$ Fahrenheit'.13

Bastian, however, in criticising Huxley's 'Biogenesis and Abiogenesis' address, attacked this idea of resistance indicating that it was just not valid. ${ }^{14}$ It is to Bastian's credit that he took steps to test the validity of the generally accepted conditions for sterilising infusions. In the first of his many books concerned with spontaneous generation, The Modes of Origin of Lowest Organisms, (London, 1871), he devoted a section to "Limits of "Vital Resistance" to Heat displayed by Bacteria and Torulae'.15 From experiments on heating solutions of ammonium tartrate and sodium phosphate inoculated with micro-organisms, Bastian concluded that growth could always be prevented by heating to $140^{\circ} \mathrm{F}$ for ten minutes. He remained convinced of this result throughout the 1870 s and when in later work ${ }^{16}$ he used organic infusions (of hay, and neutral and acid turnip) and found that growth occurred after heating to $140^{\circ} \mathrm{F}$, he ignored the possibility that micro-organisms originally present might, under the different conditions, have resisted that temperature. He considered that in such organic infusions any living organisms originally present had been killed at $140^{\circ} \mathrm{F}$, but that the temperature was inadequate to destroy the dead organic matter (ferments) which initiated the spontaneous generation of micro-organisms.

But even before Bastian published these results there had been experimental work that contradicted them. James Samuelson's studies, for example, though limited in scope, led him to conclude that

the solid floating contents of the atmosphere may be submitted to an exceedingly high temperature in the dry as well as moist condition without exterminating the living germs. ${ }^{17}$

There was also some experiments by B. T. Lowne which indicated the resistance of spores of Penicillium glaucum..$^{18} \mathrm{~A}$ more carefully performed and extensive piece of work was undertaken by F. Crace Calvert who published three papers on heat and micro-organisms ${ }^{19}$. The first, entitled 'Action of Heat on Protoplasmic Life', created considerable interest. It provided strong evidence against spontaneous generation but, as will be seen below, received justifiable criticism. He experimented with various fluids, namely sugar and gelatin solutions, hay infusion and water that had been shaken with putrid meat. These fluids were placed in small tubes and exposed to the atmosphere until micro-organisms were present, after which the tubes were hermetically

18 Disease Germs: their Supposed Nature, London, 1870, p. 50.

14 See Nature, Lond., 1870, 2, 431-434.

15 The Modes of Origin of Lowest Organisms, London, 1871, pp. 44-61.

18 'On the temperature at which Bacteria, Vibriones, and their supposed germs are killed when immersed in fluids or exposed to heat in a moist state', Proc. roy. Soc., 1872-73, 21, 224-232; and 'Further observations on the temperature at which Bacteria, Vibriones, and their supposed germs are killed when exposed to heat in a moist state; and on the causes of putrefaction and fermentation', ibid., pp. 325-338.

17' Quart. J. Sci., 1870, 7, 491.

18 See his paper 'On so-called spontaneous generation', J. Quekett Micr. Cl., 1870-71, 2, 133-140.

10 'Action of heat on protoplasmic life', Proc. roy. Soc., 1870-71, 19, 472-476; 'On the effects of heat on protoplasmic life, previously dried', Chem. News, 1871, 24, 88-90; 'On the action of heat on protoplasmic life dried on in cotton fabrics', ibid., pp. 138-140. 


\section{J. K. Crellin}

sealed and divided into groups so that the effects of four different temperatures $\left(212^{\circ}, 300^{\circ}, 400^{\circ}\right.$ or $\left.500^{\circ} \mathrm{F}\right)$ for 30 minutes could be compared on each fluid. Growth usually occurred after the $300^{\circ} \mathrm{F}$ heating but not after $400^{\circ} \mathrm{F}$ and Calvert unhesitatingly expressed his conclusion:

These experiments, therefore, clearly show that the life found by previous experimenters in fluids which have been submitted to heat was not due to heterogenesis [spontaneous generation], but to life which had remained in the fluids, as I have seen no experiments reported where the temperature to which the fluids were exposed exceeded $300^{\circ} \mathrm{F} .{ }^{20}$

The weakest point of Calvert's paper was that he did not produce sufficient evidence to show that the micro-organisms he thought had survived were in fact alive. $\mathrm{He}$ was criticised on this account by Bastian ${ }^{21}$ and W. Roberts ${ }^{22}$ while W. N. Hartley questioned the results because he felt that some of the micro-organisms could have adhered to the sides of the vessel and hence not have been subjected to the high temperature..$^{23}$ Unfortunately, the same criticism, that Calvert had not used sufficient evidence to show that surviving organisms were in fact alive, applied to his other papers.

Thus there was by 1873 much circumspect evidence to suggest that instances of alleged spontaneous generation could be attributed to the heat survival of microorganisms or rather what were considered to be their germs. Even so, opposition to Bastian's views was certainly not restricted to this concept. There was abundant criticism of his capabilities as a research worker ${ }^{24}$, with the obvious inference that his experimental technique was at fault. Apart from this there was the more constructive criticism arising out of failures to repeat some of Bastian's experiments. E. Frankland was one of the first to offer such criticism ${ }^{25}$ and this was soon followed by similar but more detailed criticism by W. N. Hartley, ${ }^{26}$ and E. Ray Lankester and C. C. Pode. ${ }^{27}$ It might be expected therefore that Bastian's efforts in support of spontaneous generation would have been totally dismissed. However, that this was not the case was, in large measure, due to a short communication from J. Burdon Sanderson. ${ }^{28}$

Burdon Sanderson, who had a first-class reputation as a careful experimenter, announced that he had witnessed some of Bastian's experiments and stated that

by following Dr. Bastian's directions, infusions can be prepared which are not deprived, by an ebullition of from five to ten minutes, of the faculty of undergoing those chemical changes which are characterised by the presence of swarms of Bacteria. ${ }^{20}$

${ }^{20}$ Proc. roy. Soc., 1870-71, 19, 475. Calvert was incorrect for Bastian had used temperatures slightly higher than $300^{\circ} \mathrm{F}$.

${ }_{21}$ The Beginnings of Life, London, 1872, vol. 1, p. 334. (footnote).

22 Phil. Trans., 1874, 164, 473 (footnote).

23 Proc. roy. Soc., 1871-72, 20, 155.

${ }^{24}$ See, for example, the reviews of The Beginnings of Life in Quart. J. Micr. Sci., 1873, 13, 59-74; and The Academy, 1872, 3, 408-412.

25 'Spontaneous generation', Nature, Lond., 1870-71, 3, 225.

26 'Experiments concerning the evolution of life from lifeless matter', Proc. roy. Soc., 1871-72, $20,140-157$.

27 'Experiments on the development of Bacteria in organic infusions', ibid., 1872-73, 21, 349-358.

28 'Dr. Bastian's experiments on the beginnings of life', Nature, Lond., 1872-73, 7, 180-181.

29 Ibid., p. 181 . 
Such confirmation of Bastian's results produced immediate protests. The Manchester physician William Roberts pointed out that growth might have been due to the fact that the entire contents of the containers had not been subjected to the boiling heat and, in consequence, he suggested that it was necessary to heat for a longer time. ${ }^{30}$ But it was in a later paper by Roberts, in the Philosophical Transactions of 1874, that the issue of heat resistance of micro-organisms was clearly raised. Much of the experimental work he had carried out showed that the heating time required for sterilisation varied according to the infusions employed, a result that certainly required an explanation. Roberts decided that in addition to environmental conditions there were inherent differences between the organisms themselves. He wrote:

1. That the germinal particles of air and water (or some of them) are capable of surviving the heat of boiling water in certain media.

2. That when we speak of different liquids and mixtures as possessing different degrees of resistance to sterilization by heat, it would be more exact to say that the germinal particles of air and water possess varying degrees of vital resistance to heat according to the nature of the media in which they subsist. ${ }^{32}$

This work was particularly influential for both Cohn and Tyndall, whose work on resistance will be discussed below, noted it. At around the same time of Roberts' studies the concept of resistance was perhaps also furthered by experiments of other workers indicating that while boiling often did not prevent growth in infusions higher temperatures did.

Burdon Sanderson, continuing work along the lines of that which had substantiated some of Bastian's results, performed further experiments to examine the effects of variation of temperature. ${ }^{33}$ Using higher temperatures he obtained, in contrast to his previous experiments, no growth in the infusions. He was very wary about interpreting the result and clearly was not thinking of resistant germs when he wrote that

although all the flasks heated above $101^{\circ} \mathrm{C}$. remained sterile, this fact affords no ground for concluding that any definite relation exists between that precise temperature and the destruction of the germinating power of the liquid in question. All that has been shown is that the chance that such a liquid will breed Bacteria is diminished either by slightly increasing the temperature to which it is heated, or increasing the duration of the heating."

Bastian, it is interesting to note, argued that he was not surprised at the result. ${ }^{35} \mathrm{He}$ wrote that because of the higher temperature used the process of fermentation would be, as he had previously found, delayed and also modified in intensity: 'it must not therefore be supposed', wrote Bastian, 'that fermentation would not have taken place at all in certain of Dr. Sanderson's flasks, simply because it had not occurred within four, five or six days'. In a further letter Bastian additionally argued that he had, in fact, found growth to occur in infusions that had been heated to temperatures even higher than Burdon Sanderson had used.96

so Ibid., p. 302.

21 'Studies on biogenesis', Phil. Trans., 1874, 164, 457-477.

22 Ibid., p. 475.

83 'Dr. Bastian's turnip-cheese experiments', Nature, Lond., 1873, 8, 141-143.

34 Ibid., p. 143.

35 Ibid., p. 161.

38 Ibid., pp. 199-200. 


\section{J. K. Crellin}

This view was further questioned, however, by a note from W. N. Hartley suggesting that temperatures above $100^{\circ} \mathrm{C}$ could prevent growth in infusions that otherwise showed growth after boiling for a short time. ${ }^{37}$ There was also a perceptive communication from E. Ray Lankester who underlined the importance of both temperature and length of heating for sterilisation. ${ }^{38} \mathrm{He}$ suggested that the relationship of temperature with the time of heating could probably be determined from a graph with these two variables plotted on the axes. Unfortunately Lankester did not experimentally confirm this idea.

Thus, by 1874, arising out of the British controversies alone there was considerable evidence to suggest that contrary to much popular belief, boiling was inadequate to ensure sterilisation of many infusions. It was also confirmed that alkaline solutions were the most difficult to sterilise. All this must have fostered the concept of the possibility of heat resistant organisms and hence must have created a favourable climate for the recognition of the role of resistant spores. Unfortunately Tyndall who contributed so much to this recognition (see below), only referred to the work of Cohn and Roberts and there is, therefore, no direct evidence, even in his practical notebooks, to indicate that the results of Burdon Sanderson, Hartley and Lankester directly affected his thinking.

In contrast, it would seem that Bastian reacted to the experiments using sterilisation temperatures above $100^{\circ} \mathrm{C}$ for, in 1874 , he published a long article, 'Heat and Living Matter'. ${ }^{39}$ As was usual with his writings it was persuasively written. He sought to establish that organisms were always killed at relatively low temperatures and summarised much published work to support this view. He also pointed out that such facts as dry seeds being more resistant to heat than wet were irrelevant to the question of the origin of organisms in fluids.

Bastian's reminder of the difference in heat sensitivity of micro-organisms was repeated when he criticised the important and valuable researches of Dallinger and Drysdale. ${ }^{40}$ Between 1873 and 1875 they published a series of studies in which they showed that many microscopic monads have two distinct phases (sporing and vegetative) in their life histories. ${ }^{41}$ They also found that these stages varied considerably in their reaction to heat in that the spore stage was far more resistant. Their conclusion was that this explained many alleged cases of spontaneous generation. They wrote that the

heating experiments have uniformly proved the fact that the spores resulting from sexual generation have a power of resistance to heat over the adult which is greater in the proportion of 11 to 6 on the average, and this appears to us to be the very essence of the question of Biogenesis versus Abiogenesis. ${ }^{42}$

Important as the work of Dallinger and Drysdale was, the more significant studies

37 Ibid., p. 200.

38 Ibid., 1873-74, 9, 421-422.

30 The Contemporary Review, 1874, 24, 516-538.

40 See pp. 77-78 of Bastian's paper 'On the conditions favouring fermentation and the appearance of bacilli, micrococci, and torulae in previously boiled fluids', J. Linn. Soc., 1879, 14, 1-94.

11 See papers in Mon. micr. J., 1873, 10, 53-58, 245-249; 1874, 11, 7-10, 69-72, 97-103; 1874, $12,261-269 ; 1875,13,185-197$.

'18 Mon. micr. J., 1875, 13, 197. 
in establishing the idea that some micro-organisms, particularly bacteria, have a heat resistant stage were by F. Cohn and J. Tyndall.

Cohn, the outstanding German authority on bacteria, strongly opposed the idea of spontaneous generation. Besides confirming some of Roberts' results on the difficulty of sterilising alkaline hay infusions, his most significant result was the demonstration that any resulting growth in hay infusions was due to Bacillus subtilis. He also observed that this organism formed spores and indicated that it was these that survived the boiling. ${ }^{43}$

There were other valuable continental studies indicating the importance of time and temperature in sterilising infusions, ${ }^{44}$ but these were hardly significant when compared with Tyndall's studies. In 1876 Tyndall published the results of many experiments which showed that boiled infusions could be kept sterile if exposed to an atmosphere free from particulate matter. ${ }^{45}$ Later, ${ }^{46}$ following Cohn's confirmation of some of Roberts work, Tyndall repeated his experiments to find that they no longer gave consistent results and that boiling, therefore, was not always sufficient to prevent growth. Tyndall came to realise that his results could be interpreted as follows: (1) that infusions prepared from old dried hay (containing desiccated, and hence hardened, resistant germs) were more difficult to sterilise than infusions of fresh hay, and (2) that resistant germs were often to be found in the atmosphere.

Tyndall confirmed the idea of resistant germs by determining their 'resistance limit'-in one instance he obtained growth after eight hours' boiling. This work was carefully performed in order to show that resistant germs actually existed in his infusions. It is perhaps surprising that Tyndall did not discuss the effects of temperatures higher than $100^{\circ} \mathrm{C}$, but he did introduce the method of sterilisation by discontinuous heating (Tyndallisation). ${ }^{47}$

Seen in the light of all the other evidence that had been accruing on the need to use adequate temperatures and length of heating to ensure sterilisation it would seem that Tyndall's work presented a water-tight argument favouring the idea of a resistant stage in the life cycle of certain micro-organisms. Even so his studies did not escape criticism. 'Inquirer' was sceptical about Tyndall's 'special theory',48 but not so forthright as Bastian. ${ }^{49}$ It is amusing to note that the animosity between him and Tyndall was such that Bastian deliberately absented himself from the reading of Tyndall's paper at the Royal Society. ${ }^{50}$

Bastian, in fact, was at the time in the midst of controversy with Pasteur over the interpretation of why growth appeared in alkaline urine after it had been boiled

\footnotetext{
48 See Cohn's paper, 'Untersuchungen über Bacterien', Beitr. Biol. Pfl., 1876-77, 2, 249-276.

14 Such studies were carried out under the direction of Pflüger and Hoppe-Seyler and by Huizinga. Burdon Sanderson was instrumental in drawing them to the particular attention of British workers in The Academy, 1875, 8, 15-16, 41-43 (a review of Bastian's Evolution and the Origin of Life, London, 1874), and in a paper in Proc. roy. Soc., 1877, 26, 416-426.

${ }_{45}$ 'The optical deportment of the atmosphere in relation to the phenomena of putrefaction and infection', Phil. Trans., 1876, 166, 27-74.

46 'Further researches on the deportment and vital persistence of putrefactive and infective organisms from a physical point of view', ibid., 1877, 167, 149-206.

47 'On heat as a germicide when discontinuously applied', Proc. roy. Soc., 1876-77, 25, 569-570.

48 The Contemporary Review, 1876-77, 29, 915.

${ }^{9}$ See, for example, his article 'Spontaneous generation: A reply', The Nineteenth Century, 1878, 3, 261-277.

${ }^{50}$ The Times, 26 June 1877, p. 4.
} 


\section{J. K. Crellin}

for a few minutes. ${ }^{51}$ Pasteur, naturally, felt that growth was due to survival of microorganisms, whereas Bastian considered it was the effect of alkali initiating and favouring chemical changes which led to the origin of micro-organisms. Bastian confirmed his idea by experiments in which he boiled acid urine for a few minutes in a retort-like flash which also contained a fragile glass specimen tube containing potash. After the acid urine had been boiled the potash could be readily liberated by breaking its container. Pasteur and his followers were surprised that Bastian obtained growth at the end of his experiments for it was generally accepted that all organisms would be destroyed in boiling acid urine and also inconceivable that any survived in the potash. Nevertheless after much dispute Bastian's results were accepted, though the correct interpretation was that growth was due to resistant spores. Arising out of this controversy Chamberland and Pasteur determined that, to ensure sterilisation, heating should be effected at around $115^{\circ} \mathrm{C}$.

Bastian, however, up to the time of his death fifty years ago, in November 1915, never gave up the idea of spontaneous generation, nor did he accept the idea that spores were sufficiently resistant to account for growth in infusions that had been boiled for a short while. ${ }^{52}$ Nevertheless, by the end of the 1870 s, the theory of the spontaneous generation of micro-organisms could no longer withstand informed scrutiny for it had been undermined by knowledge on thermal resistance as well as by other less important evidence such as on the widespread dissemination of microorganisms and methods of handling them.

51 There were innumerable publications in this controversy. A convenient account of them is given by Bastian in his The Evolution of Life, London, 1907, p. 151 et seq.

${ }^{52}$ See his The Evolution of Life, London, 1907, pp. 67-86.

\section{SELECT BIBLIOGRAPHY}

(Only the more important references given in the text are included)

Bastian, H. C., The Modes of Origin of Lowest Organisms, London, 1871.

The Beginnings of Life, London, 1872.

The Evolution of Life, London, 1907.

'On the temperature at which Bacteria, Vibriones, and their supposed germs are killed when immersed in fluids or exposed to heat in a moist state', Proc. roy. Soc., 1872-73, 21, 224-232.

- Further observations on the temperature at which Bacteria, Vibriones, and their supposed germs are killed when exposed to heat in a moist state; and on the causes of putrefaction and fermentation', ibid., pp. 325-338.

'Heat and living matter', The Contemporary Review, 1874, 24, 516-538.

Beale, L., Disease Germs: Their Supposed Nature, London, 1870. 
Heat Resistance of Micro-Organisms in British Spontaneous Generation Controversies

Burdon Sanderson, J., 'Dr. Bastian's experiments on the beginnings of life', Nature, Lond., 1872-73, 7, 180-181.

'Dr. Bastian's turnip-cheese experiments', ibid., 1873, 8, 141-143.

Calvert, F. C., 'Action of heat on protoplasmic life', Proc. roy. Soc., 1870-71, 19, 472-476.

CHIID, G., Essays on Physiological Subjects, London, 1868.

'Further experiments on the production of organisms in closed vessels', Proc. roy. Soc., 1865, 14, 178-186.

CoHN, F., 'Untersuchungen über Bacterien', Beitr. Biol. Pfl., 1876-77, 2, 249-276.

Dallinger, W. H. and DRYSDALE, J., A series of papers on the life histories of monads, Mon. Micr. J., 1873, 10, 53-58, 245-249; 1874, 11, 7-10, 69-72, 97-103; 1874, 12, 261-269; 1875, 13, 185-197.

HARTLEY, W. N., 'Dr. Bastian's experiments', Nature, Lond., 1873, 8, 200.

HuXLEY, T. H., 'Biogenesis and abiogenesis', Report of the British Association for the Advancement of Science 1870, London, 1871, pp. Ixxiii-lxxxix.

LANKESTER, E. RAY, 'An experiment on the destructive effect of heat upon the life of bacteria and their germs', Nature, Lond., 1873-74, 9, 421-422.

Lowne, B. T., 'On so-called spontaneous generation', J. Quekett Micr. Cl., 1870-71, 2, 133-140.

ROBERTs, W., 'Dr. Bastian's experiments on the beginnings of life', Nature, Lond., 1872-73, 7, 302.

-Studies on biogenesis', Phil. Trans., 1874, 164, 457-477.

SAmuelson, J., 'The controversy of spontaneous generation: with recent experiments', Quart. J. Sci., 1870, 7, 484-497.

TYNDALL, J., 'Further researches on the deportment and vital persistence of putrefactive and infective organisms from a physical point of view', Phil. Trans., 1877, 167, 149206. 